\title{
KONTROL KELUARGA TERHADAP PENCEGAHAN KENAKALAN REMAJA
}

\author{
Sarah Rodia Natasya, Ruslan, Sanusi ${ }^{\varpi}$ \\ Jurusan Pendidikan Pancasila dan Kewarganegaraan, Fakultas Keguruan dan Ilmu Pendidikan, \\ Universitas Syiah Kuala
}

\section{Info Artikel \\ Sejarah Artikel: \\ Disubmit: Januari 2021 \\ Direvisi: Februari 2021 \\ Diterima: Maret 2021 \\ Keywords: \\ Parental Control, \\ Juvenile Delinquency}

\begin{abstract}
Abstrak
Masa remaja ialah sesuatu pergantian pada remaja yang sangat rentan timbulnya sesuatu permasalahan yang paling utama didalam kenakalan remaja. Butuh adanya suatu perhatian khusus serta pemahaman yang baik serta penjelasan yang tepat terhadap remaja tersebut. Penelitian ini merupakan penelitian yang tergolong ke dalam jenis penelitian deskriptif dengan pendekatan kualitatif, Istrumen pengumpulan data menggunakan wawancara secara mendalam untuk mendapatkan data dilapangan. Simpulan penelitian ini adalah bahwa Kenakalan remaja terjadi karena tidak adanya pengawasan dan perhatian dari orang tua dan lingkungan terhadap pertumbuhan anakanak, dan kurangnya penanaman nilai agama di lingkungan di mana anak-anak itu tumbuh dan berkembang. Saran dari penelitian ini adalah Orang tua wajib jadi teladan sikap serta perkataan pada anaknya, motivasi anak, orangtua berikan arahan dengan siapa serta di komunitas mana remaja wajib berteman dan bergaul. Orang tua berupaya menghasilkan keluarga yang harmonis, komunikatif, serta aman untuk remaja itu sendiri. Dan menolong remaja untuk pandai memilih teman serta lingkungan yang baik. Dan juga memberikan suatu kegiatan yang positif yang membuat remaja merasa nyaman berada di dalam lingkungan masyarakat.
\end{abstract}

Abstract
Adolescence is a turn in adolescents who are very vulnerable to the emergence of a problem that is
the most important in juvenile delinquency. It takes special attention and a good understanding and
proper explanation of the problem. This research is a research that belongs to the type of descriptive
research with a qualitative approach, the data collection instrument uses in-depth interviews to
obtain data in the field, the conclusion of this study is that juvenile delinquency occurs due to the
absence of supervision and attention from parents as well as the environment towards children's
growth, and the lack of inculcation of religious values in the environment in which the children grow
and develop. Suggestions from this study are that parents must be role models, and have good
attitudes towards children, motivate children, as well as provide directions with whom and which
community where youth can make friends and get along. Parents strive to produce a harmonious,
communicative, and safe family for the teenagers themselves, helping them to be able and smart in
choosing friends and a good environment. Also provides a positive activity that makes teenagers feel
comfortable in the community. (C) 2021 Universitas Negeri Semarang

Alamat korespondensi: E-ISSN 2685-4929

FKIP, Universitas Syiah Kuala

Email:ruslan@unsyiah.ac.id 


\section{PENDAHULUAN}

Perkembangan teknologi yang sangat begitu pesatnya menyimpan bahwa banyak problematika yang sangat penting yang mana bisa mengakibatkan runtuhnya nilai moral itu sendiri, dan juga nilai yang tertanam di dalam diri anak remaja yang terjadi ditengah pertumbuhannya itu dikarenakan dengan begitu mudahnya mereka berkomunikasi dengan orang lain dengan menggunakan teknologi yang ada pada saat ini , serta mudahnya juga mereka untuk mengakses informasi-informasi yang seharusnya tidak semestinya mereka harus lihat atau mereka dengarkan.

Masa remaja ialah masa yang sangat menyenangkan sekaligus masa yang sangat sulit didalam kehidupan hidup seseorang. Yang mana pada masa ini seseorang baru memulai untuk mencari jati diri pada mereka untuk menjadi sosok seorang remaja. Tetapi belum sepenuhnya juga dapat di anggap sebagai orang yang telah dewasa. Disatu sisi remaja ini ingin bebas dan juga mandiri, lepas dari ini semua pengaruh dari orang tua, disisi lain juga pada dasarnya remaja ini tetap membutuhkan dukungan serta perlindungan dari orang tuanya.

Remaja sebagai generasi penerus bangsa merupakan individu yang berkembang tidak hanya pada aspek kecerdasan intelektual, namun juga berkembang pada aspek karakter yang berbudi luhur dan bermartabat. Saat ini remaja mencari pola hidup yang paling sesuai untuknya dan disini pun remaja melakukan kesalahan yang dilakukan melalui metoda coba-coba. (Stephen \& Ekpenyong (2015) menyebut juvenile delinquency (kenakalan remaja) adalah sebagai suatu fenomena yang dialami oleh masyarakat di seluruh dunia, yang mana kenakalan remaja ini merupakjan suatu masalah yang sangat penting yang harus diselidiki dan ditangani dengan hatihati, karena anak remaja atau kaum muda saat ini merupakan suatu cerminan dari para pemimpin di masa depan yang akan datang.

Remaja yang di maksudkann disini adalah mereka biasanya antara usia 13 sampaii 20 tahun (Potter \& Perry, 2010). Mengatakan bahwa Masa remaja yaitu suatu masa yang mana merupakan masa yang sangat menyenangkan dan sekaligus masa yang sangat sulit yang di hadapi di dalam hidup seseorang. Yang mana Di masa inilah seorang anak dapat mulai untuk mencari jati diri untuk bisa menjadi seorang remaja. Kurniawan (2015: 42) mengatakan bahwa tri pusat pendidikan merupakan tiga pusat yang memiliki tanggung jawab atas terselenggaranya pendidikan terhadap anak, tiga pusat tersebut merupakan pendidikan dalam keluarga, dalam sekolah dan dalam masyarakat.

Di masa seperti sekarang ini banyak permasalah yang terjadi, seperti ketidaksiapan orang tua didalam membina anak-anak mereka. Yang mana sering dianggap sebagai pemicu terjadinya suatu permasalah sosial dan suatau kenakalan remaja, dikarenakan bahwa orang tua ini dinilai kurang mampu dalam memberikan perhatian khusus kepada anaknya. (Tangkudung, 2014).

Tanpa disadari pada zaman sekarang ini, banyak remaja terjerat dalam pengaruh narkoba, seks bebas, dan kenakalan remaja lainnya perkelahian sampai masalah paling parah, seperti tindakan kriminal. Komunikasi dengan keluarga terutama orang tua, memiliki peranan penting bagi anak tersebut, karena itu berpengaruh besar terhadap pengaruh lingkungan dan pergaulan anak. karena perkembangan anak lebih banyak dipengaruhi oleh lingkungan. Menurut Aini (2017) yang dalam penelitiannya menyatakan bahwa keluarga itu merupakan suatau lingkungan sosial pertama yang memberikan pengaruh sangat besar bagi tumbuh kembang seorang pelajar.

Kenakalan remaja ini biasanya dilakukan para remaja-remaja yang mana mereka gagal dalam menjalani suatu proses-proses perkembangan jiwanya mereka, baik dari sisi pada saat mereka remaja maupun pada saat mereka kanak-kanak. Masa kanak-kanak dan masa remaja ini berlangsung sangat singkat, dengan perkembangan fisik, psikis, dan emosi yang begitu cepat. Secara psikologis, kenakalan remaja ialah suatu bentuk dari konflik-konflik yang tidak terselesaikan dengan baik pada masa kanak-kanak maupun remaja, contohnya mendapat perlakuan kasar dan tidak menyenangkan dari lingkungan mereka dan kondisi ekonomi yang menyebabkan mereka merasa rendah diri. 
Dengan kata lain, bahwa secara ideal perkembangan diri seorang pelajar akan optimal apabila mereka bersama keluarganya. Tentu saja yang mana di dalam suatu keluarga yang dimaksud merupakan keluarga yang sanagat harmonis, sehingga pelajar memperoleh berbagai jenis kebutuhan, seperti kebutuhan fisik-organis, sosial maupun psiko-sosial.

Di perkuat dengan penelitian dari Penelitian yang di lakukan oleh Genta Sakti ,Neila Sulung (2020) tentang Peran Komunikasi Dalam Keluarga Terhadap Perilaku Menyimpang Anak Dan Remaja (Systematic Review) mengatakan bahwa pada artikel internasional bahwa komunikasi dalam keluarga positif sangat membantu mencengah perilaku menyimpangan pada remaja, dan keluarga yang haromis kecendrungan akan menghasilkan anak berperilaku positif dan mempunyai kepercayaan diri yang tinggi. Pengawasan yang di lakukan oleh orang tua terutama wanita, dapat dikatakan lebih efektif untuk menurunkan angka kejadian suatu penyimpangan perilaku pada remaja.

Untuk mencegah terjadinya suatu kenakalan remaja yaitu bisa dengan cara menciptakan suatu komunikasi yang harmonis yaitu antara orang tua dan anak,karena cara tersebut akan menjadi suatu modal yang sangat penting dalam mencegah terjadinya pergaulan yang sangat bebas. Jadi titik terpenting dalam mencegah terjadinya kenakalan remaja adalah peran orangtua untuk menolong anak remajanya supaya mereka tidak salah jalan nantinya ketika mereka sudah mulai dewasa. Tujuan nya untuk mendeskripsikan bagaimana bentuk kontrol keluarga terhadap pencegahan kenakalan remaja dan Apa yang menjadi hambatan keluarga dalam Pencegahan kenakalan remaja.

Manfaat nya dari hal ini yaitu bagi anak bisa mengetahui hubungan antara lingkungan di dalam keluarga dengan lingkungan sekitar, sehingga anak bisa membedakan agar nantinya tidak salah dalam pemahaman. Bagi orang tua Dengan penelitian ini, orang tua diharapkan bisa menjadi motivasi atau masukan bagi anak agar mereka tidak salah nantinya bergaul di dunia luar nantinya.

Peran dari orang tua diantaranya dengan memberikan suatu pendidikan yang dimulai dari hal yang kecil kepada anak . dan juga Anak tersebut sebaiknya diberikan akan suatu pengetahuan yang baik. Yang mana Orang tua sebaiknya mendidik anak itu dengan penuh tanggung jawab dan kedisiplinan. Nilai Tanggung jawab sangatlah diperlukan dalam hal mengembangkan kepribadian pada anak. Yang mana Orang tua harus lebih mengajarkan kepada anak tentang betapa pentingnya suatu arti dari tangung jawab dan nilai Kedisplinan juga sangat berperan penting di dalam perkembangan anak, yang mana nantinya anak tersebut tidak terbiasa dengan bergantung kepada orang lain karena kemalasan atau dengan suatu alasan . disinilah pentingnya Peran orang tua didalam memberikan suatu perhatian dan kasih sayang pada anak. karena itu sangat diperlukan anak untuk menjaga suatu hubungan dalam perkembangannya nanti.

Dibutuhkan akan kebutuhan rasa aman dan nyaman yaitu dengan memberikan kebutuhan pada anak dan lingkungan yang stabil dan aman bagi mereka . hal ini merupakan suatu Kebutuhan yang sangat penting untuk pembentukan karakter dari anak tersebut. Dikarenkan lingkungan yang terkadang berubah-ubah akan membahayakan bagi perkembangan emosi mereka . Kekacauan emosi yang terjadi pada anak dikarenakan tidak adanya rasa aman bagi pertumbuhan anak yang optimal.

Tugas utama dari pendidikan adalah untuk membangun karakter (character building) seorang pada anak, dan hal ini dimulai dari sebuah sebuah keluarga. Pendidikan karakter pada anak yang dilakukan oleh orangtua dari berbagai macam budaya pada saat ini bakal menjadi cikal bakal pada anak yang nantinya menghormati orang tua, bersikap santun, jujur, berbahasa halus dan berbudi perkerti yang baik. Modal dasar pada anak yang sudah berkarakter baik yang dididik dari keluarga baik dan sejahtera akan mempermudah dunia pendidikan mencetak anak-anak yang berkualitas.

Mengingat remaja sebagai generasi muda yang mana merupakan sumber daya manusia yang sangat potensial bagaikan penerus citacita bangsa, yang mempunyai peranan yang sangat berarti. Mereka membutuhkan perlindungan dan pembinaan serta bimbingan untuk menjamin kebutuhan fisik, mental, dan spiritual secara utuh. Dalam memberikan perlindungan dan bimbingan kepada remaja, diperlukan dukungan yang 
positif, partisipasi aktif dari seluruh pihak yang paling utama orang tua. Dalam perihal ini orang tua butuh membina mentalitas anak remaja dengan menanamkan nilai agama.

\section{METODE}

Metode yang digunakan di dalam penelitian ini adalah metode penelitian kualitatif yang bersifat deskriptif. Penelitian bertujuan untuk memperoleh gambaran seutuhnya mengenai suatu hal menurut pandangan manusia yang diteliti.Penelitian kualitatif berhubungan dengan ide, persepsi, pendapat atau kepercayaan orang yang diteliti dan kesemuanya tidak dapat diukur dengan angka.

Penelitian ini bertempat di Kecamatan Suka Makmur Kabupaten Aceh Besar. Pemilihan subyek dalam penelitian ini adalah dilakukan secara purposive sampling. subyek yang gunakan dalam penelitian ini adalah orang tua dan remaja dengan mengambil 10 orang yang terdiri dari 5 orang tua dan 5 remaja. Teknik pengumpulan data yang digunakan dalam penelitian ini meliputi, Wawancara pada orang tua dan remaja.

Dalam analisis data yang dilakukan pada penelitian ini, dimana Teknik pengumpulan data nya di gunakan Pada penelitian ini memilih jenis penelitian kualitatif oleh karena itu data yang diperoleh haruslah mendalam, jelas dan spesifik. analisis data tersebut dilakukan dengan proses pengumpulan data secara (1) Reduksi data (2) Penyajian Data (3) Penarikan Kesimpulan/ Verifikasi

\section{HASIL DAN PEMBAHASAN}

Salah satu kasus yang sangat perlu mendapatkan perhatian khusus dalam pembangunan manusia seutuhnya merupakan manusia yang berkaitan dengan generasi muda, terkhususnya kenakalan remaja yang saat ini kerap kali terjadi berbagai kasus yang berhubungan dengan permasalahan kenakalan remaja Keluarga ialah lingkungan yang sangat berarti bagi remaja untuk belajar bersosialisasi.

Bentuk kontrol keluarga terhadap pencegahan kenakalan remaja

Berdasarkan hasil pengumpulan data dari peneliti bahwa, kenakalan remaja ini sangat rentan terjadi, banyak dari remaja tersebut yang sudah merokok, balap liar di lingkungan dan mereka juga sering berkumpul-kumpul hanya untuk melakukan hal yang tidak bermanfaat seperti yang di katakan oleh informan yang mana itu dapat memicu terjadinya hal-hal yang tidak di inginkan. Hal ini di akibatkan karena kurangnya perhatian orang tua mereka, atau orang tua yang tidak mau tau menau tentang aktivitas yang dilakukan oleh anak mereka. Kenakalan remaja ini juga bisa terjadi dikarenakan kurangnya dasar agama. Oleh karena itu pentingnya dasar agama yang harus ditetapkan oleh orang tua terhadap anak ketika masih kecil.

tidak ada orang tua yang tidak memerhatikan anak nya, pastinya orang tua akan selalu mengawasi anaknya agar tidak terjerumus ke dalam hal-hal yang negatif. Kenakalan remaja dapat kita cegah dengan memberikan hal-hal yang positif kepada anak tersebut, agar mereka tidak mudah terpengaruh ke hal-hal yang tidak baik. Banyak dari mereka yang terpengaruh dari teman ataupun lingkungan sekitar, lingkungan harus menerapkan kegiatan-kegiatan yang positif yang melibatkan remaja di dalamnya. Seorang informan mengatakan adanya kegiatan berzikir, dan bershalawat, yang mana itu akan memicu rendahnya perilaku menyimpang yang di lakukan oleh remaja. Dengan kita menerapkan ilmu agama kepada mereka, mereka akan tau yang baik atau tidak baiknya suatu kegiatan. Namun, tidak hanya dari lingkungan sekitar tapi kontrol dari orang tua juga sangat berpengaruh terhadap pribadi anak tersebut.

Yang mana pengendalian sosial ini merupakan suatu proses yang direncanakan atau tidak direncanakan dengan tujuan mengajak, membimbing, bahkan memaksa untuk mematuhi aturan yang berlaku agar tidak melakukan penyimpangan.

Berdasarkan hasil wawancara yang mana orang tua hanya memberikan nasehat atau peringatan kepada anak mereka, namun ketika orang tua bekerja ataupun ketika anak sudah keluar dari rumah pastinya orang tua tidak tau apa yang mereka lakukan ketika di luar rumah. Pengawasan yang di lakukan orang tua dikatakan kurang efektif, dibuktikan dengan penjelasan dari informan yang mengatakan bahwa 
ketidakpekaan orang tua yang membuat pengawasan tersebut tidak berjalan semestinya.

Adapun pengawasan dari masyarakat juga harus menyatukan untuk memahami, mengelola, serta mengajak remaja untuk mengembangkan diri secara positif, sehingga ketika di masa depan nanti dapat tumbuh menjadi generasi yang matang, dewasa dan berkualitas.

Hambatan keluarga dalam pencegahan kenakalan remaja

hasil wawancara dengan informan yang mengatakan bahwa kendalanya anak tersebut tidak mau mendengarkan nasehat dan tidak jujur terhadap apa yang mereka lakukan. Dan kurangnya pengetahuan agama yang mana membuat orang tua sedikit was-was dikarenakan zaman sekarang banyak remaja yang terpengaruh dengan gaget/hp dan teman mereka. Yang mana itu sangat ditakutkan nantinya sangat mudah terpengaruh terhadap mereka.

Alasan remaja tidak mau mendengar nasehat dari orang tua dikarenakan orang tua tidak tegas dalam berbicara kepada anak. Yang mana berdasarkan hasil wawancara dengan informan mengatakan bahwa, orang tua terkadang cuek dan bersikap biasa saja kepada mereka dan tidak tegas dalam bersikap kepada anak. Penyebab terjadinya kenakalan remaja saat ini berasal dari dalam diri remaja sendiri atau faktor yang datang dari luar dirinya. Hal ini menjadi landasan bagi orang tua dalam menyelesaikan masalah remaja secara baik dan benar.

Seperti hasil penelitian dengan informan yang mengatakan bahwa sebagai orang tua harus memperhatikan kebutuhan mental spritual anak remajanya sebagai benteng kokoh dalam diri anak dalam menghadapi tantangan zaman yang semakin berat. Terwujudnya karakter pada remaja akan berdampak positif untuk dirinya dan untuk orang sekitarnya. Seperti salah satu hasil wawancara dengan informan yang mana beliau mengatakan harus memberikan kegiatankegiatan yang positif kepada anak agar mereka sibuk dengan kegiatan tersebut dan seharusnya remaja harus berkumpul dengan orang kreatif agar nantinya mereka akan menjadi generasi yang unggul yang dapat membanggakan dan bisa di andalkan, karena di pundak merekalah bagaimana nasib masa depan bangsa dan negara ini.

\section{SIMPULAN}

Bentuk kontrol keluarga terhada pencegahan kenakalan remaja di kecamatan suka makmur kabupaten aceh besar yaitu : (1) Memberikan kegiatan yang positif kepada anak (2) Memberikan pedoman dalam pendidikan agama (3) Memberikan nasehat.

Kendala yang dihadapi orang tua dalam mencegah kenakalan remaja yaitu : (1) Pengaruh dari teman pada masa remaja ini, anak sudah mulai berani untuk melakukan kegiatan dengan lawan jenisnya dalam berbagai macam kegiatan. Misalnya kelompok teman sebaya pada masa remaja cenderung mempunyai sesuaitu kombinasi individu-individu dari bemacam kelompok. (2) Minimnya pemahaman anak tentang agama di dalam keluarga Dalam pembinaan moral, agama mempunyai peranan yang sangat penting karena nilai-nilai moral yang datangnya dari agama tetap tidak berubah karena perubahan waktu dan tempat. (3) Pengaruh lingkungan Di dalam kehidupan bermasyarakat, remaja kerap melaksanakan keonaran serta mengusik ketentraman masyarakat karena terpengaruh dengan budaya barat ataupun pergaulan dengan teman sebayanya yang kerap mempengaruhi untuk mencoba. (4) Sikap tidak mau tau atau kurang kepekaan remaja terhadap perhatian yang di berikan orang tua. Sikap tidak jujur dan tidak mau mendengar nasehat orang tua yang banyak di keluhkan oleh para orang tua terhadap anak mereka yang mana membuat orang tua sedikit was-was dikarenakan zaman sekarang banyak remaja yang terpengaruh dengan gaget/hp dan teman mereka.

\section{DAFTAR PUSTAKA}

Aini, L. N. (2017). Hubungan Pola Asuh Orang Tua dengan Kenakalan Remaja di RW V Kelurahan Sidokare Kecamatan Sidoarjo. Jurnal Keperawatan dan Kebidanan, 6(1). 
Ghufron, M. N., \& Risnawita, R. (2014). Teori - teori psikologi. Yogyakarta: ArRuz Media.

Kartini K, (2013). Kenakalan remaja. Jakarta : Rajawali Pers

Kurniawan, M. I. (2015). Tri Pusat Pendidikan Sebagai Sarana Pendidikan Karakter Anak Sekolah Dasar. Pedagogia: Jurnal Pendidikan, 4(1), 41-49.

Potter, A., \& Perry, A.G. (2010). Buku Ajar Fundamental Keperawatan: Konsep, Proses, Praktik. Edisi 7. Jakarta: EGG

Stephen, E.N., and Ekpenyong, O.A. 2015. "School Climate and Juvenile Delinquency: A Comparative Study of Two Secondary Schools in Bayelsa State". The International Journal Of Humanities \& Social Studies, Vol. 3(8), pp.77-85. (Diunduh dari http://theijhss.com/force_download)
Tangkudung, J. (2014). Peranan Komunikasi Keluarga Dalam Mencegah Kenakalan Remaja Di Kelurahan Malalayang I Kecamatan Malalayang Oleh. Tesis, III(1).

Wu, S.I., Hung, J.M. 2008. A Performance Evaluation Model of CRM on Nonprofit Organizations. Journal Vol 19(4).

Zamroni, 2001. Pendidikan Untuk Demokrasi. Yogyakarta: Bilgraf Publising. 